WSRC-STI-2007-00500, Rev. 0

\title{
CHARACTERIZATION OF H-CANYON CONDUCTIVITY METER INDICATIONS WITH ELEVATED URANIUM IN NITRIC ACID
}

October 31, 2007

Actinide \& Chemical Technology Savannah River National Laboratory Aiken, SC 29808

Prepared for the U.S. Department of Energy Under

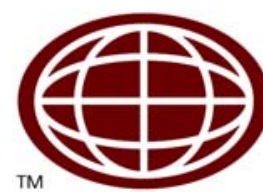




\section{DISCLAIMER}

This report was prepared as an account of work sponsored by an agency of the United States Government. Neither the United States Government nor any agency thereof, nor any of their employees, nor any of their contractors, subcontractors or their employees, makes any warranty, express or implied, or assumes any legal liability or responsibility for the accuracy, completeness, or any third party's use or the results of such use of any information, apparatus, product, or process disclosed, or represents that its use would not infringe privately owned rights. Reference herein to any specific commercial product, process, or service by trade name, trademark, manufacturer, or otherwise, does not necessarily constitute or imply its endorsement, recommendation, or favoring by the United States Government or any agency thereof or its contractors or subcontractors. The views and opinions of authors expressed herein do not necessarily state or reflect those of the United States Government or any agency thereof.

\section{Printed in the United States of America}

This document was prepared in conjunction with work accomplished under Contract No. DE-AC09-96SR18500 with the U. S. Department of Energy. 


\title{
Key Words: \\ Uranium \\ Nitric \\ Conductivity \\ Dissolution
}

Retention: Permanent

Key Reference:

Technical Task Request: NMMD-HTS-2006-2925

\section{CHARACTERIZATION OF H-CANYON CONDUCTIVITY METER INDICATIONS WITH ELEVATED URANIUM IN NITRIC ACID}

\author{
C. A. Nash
}

October 31, 2007

Actinide \& Chemical Technology Savannah River National Laboratory Aiken, SC 29808

Prepared for the U.S. Department of Energy Under
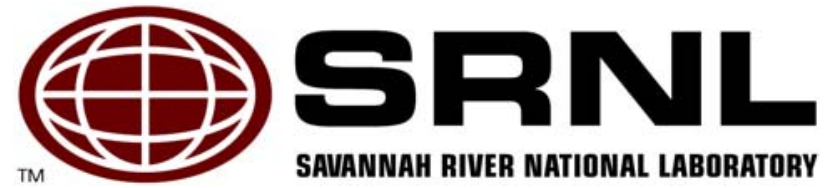
Contract Number DE-AC09-96SR18500 


\section{SUMMARY}

Solution conductivity data from the $1 \mathrm{CU}$ conductivity meter in H-Canyon shows that uranium concentration in the 0 to 30 gram per liter $(\mathrm{g} / \mathrm{L})$ range has no statistically significant effect on the calibration of free nitric acid measurement. Based on these results, no additional actions are needed on the 1CU Conductivity Meter prior to or during the processing of uranium solutions in the 0 to $30 \mathrm{~g} / \mathrm{L}$ range. A model based only on free nitric acid concentration is shown to be appropriate for explaining the data. Data uncertainties for the free acid measurement of uranium-bearing solutions are $8.5 \%$ or less at $95 \%$ confidence. The analytical uncertainty for calibrating solutions is an order of magnitude smaller only when uranium is not present, allowing use of a more accurate analytical procedure.

Literature work shows that at a free nitric acid level of $0.33 \mathrm{M}$, uranium concentration of 30 $\mathrm{g} / \mathrm{L}$ and $25{ }^{\circ} \mathrm{C}$, solution conductivity is $96.4 \%$ of that of a uranium-free solution. The level of uncertainties in the literature data and its fitting equation do not justify calibration changes based on this small depression in solution conductivity.

This work supports preparation of H-Canyon processing of Super Kukla fuel; however, the results will be applicable to the processing of any similar concentration uranium and nitric acid solution. Super Kukla fuel processing will increase the uranium concentration above the nominal zero to $10 \mathrm{~g} / \mathrm{L}$ level, though not above $30 \mathrm{~g} / \mathrm{L}$. This work examined free nitric acid levels ranging from 0.18 to 0.52 molar. Temperature ranged from 27.9 to $28.3{ }^{\circ} \mathrm{C}$ during conductivity testing. The data indicates that sequential order of measurement is not a significant factor. The conductivity meter was thus flushed effectively between measurements as desired. 


\section{REVIEWS AND APPROVALS}

Author:

C. A. Nash, SRNL Actinide \& Chemical Technology

Date

Technical Review:

R. J. Lascola Jr., SRNL Spectroscopy and Separations

Date

SRNL Management:

S. D. Fink, Manager, SRNL Separations Science Programs

Date

A. M. Murray, Manager, SRNL Actinide \& Chemical Technology

Date

\section{Customers:}

S. L. Hudlow, H-Canyon Process Engineering

Date

P. B. Andrews, Manager, H-Canyon Process Engineering

Date

R. L. Huffines, Manager, H-Canyon Process Engineering

Date 


\section{TABLE OF CONTENTS}

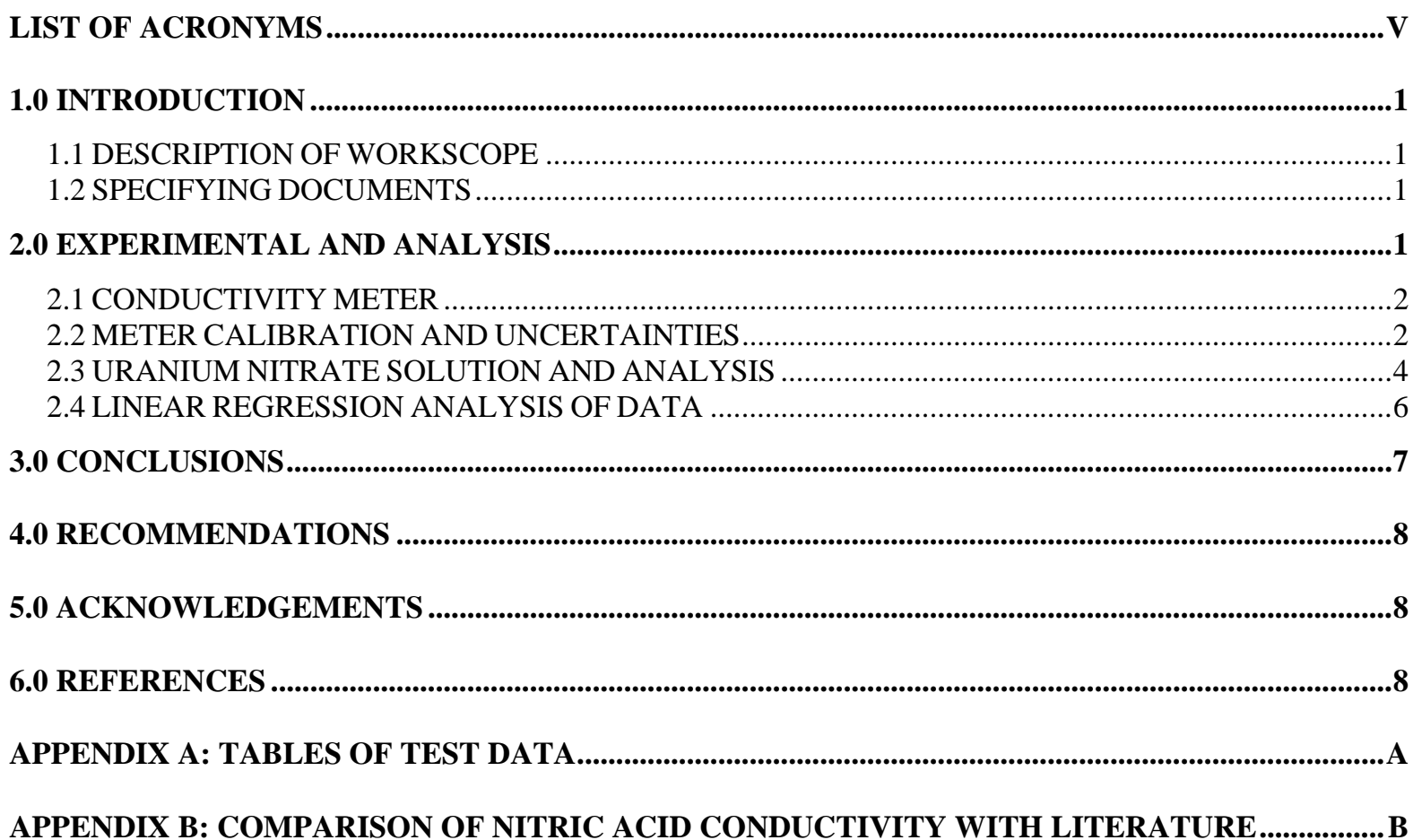

\section{TABLE OF TABLES}

TABLE 1. Results Of THE 9/06/2007 CALIBRATION OF THE 1CU METER...........................................................

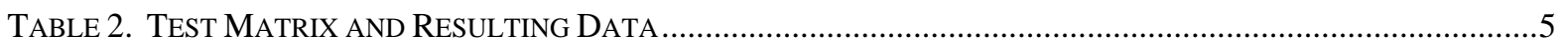

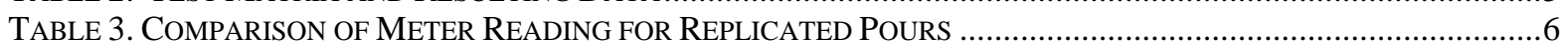




\section{List of Acronyms}

$\begin{array}{ll}\text { A\&CT } & \text { Actinide and Chemical Technology } \\ \text { AD } & \text { Analytical Development } \\ \text { AL } & \text { Analytical Laboratories (F/H Area Laboratory Services) } \\ \text { cm } & \text { centimeters } \\ \text { CRC } & \text { Chemical Rubber Company (Handbook, ref. 14 of report) } \\ \text { DUN } & \text { Depleted Uranium Nitrate (solution) } \\ \text { Free H } & \text { Free acid as reported by the conductivity meter at the chart recorder } \\ \text { g } & \text { Grams } \\ \text { ICP-ES } & \text { Inductively Couple Plasma-Emission Spectroscopy } \\ \text { ICP-MS } & \text { Inductively Couple Plasma-Mass Spectrometry } \\ \text { ICT } & \text { International Critical Tables (ref. } 9 \text { of report) } \\ \text { L } & \text { Liter } \\ \text { M } & \text { Molar } \\ \text { mS } & \text { Millisiemens (conductance, (1/ohm)*1000) } \\ \text { MS\&E } & \text { Measurement Systems and Equipment } \\ \text { MS\&T } & \text { Materials Science and Technology } \\ \text { Nitr } & \text { Concentration of free nitric acid in standard solutions, M } \\ \text { SK } & \text { Super Kukla (reactor) } \\ \text { SRNL } & \text { Savannah River National Laboratory } \\ \text { SRS } & \text { Savannah River Site } \\ \text { T } & \text { Solution temperature in the conductivity meter, }{ }^{\circ} \mathrm{C} \\ \text { TTQAP } & \text { Technical Task and Quality Assurance Plan } \\ \text { TTR } & \text { Technical Task Request } \\ \text { U } & \text { Uranium concentration in solution, g/L metal basis } \\ \text { UET } & \text { Use Every Time } \\ \text { TCU } & \text { Uranium solution stream exiting the 14.3M mixer-settler bank } \\ \end{array}$




\subsection{INTRODUCTION}

\subsection{DESCRIPTION OF WORKSCOPE}

This work provides measurement and analysis of the effect that dissolved uranium at higher than normal concentrations has on hydrogen ion measurements through electrical conductivity. Data were obtained in-facility using the H-Canyon 1CU conductivity meter. "1CU" refers to the uranium stream exiting the $1 \mathrm{C}$ or $14.3 \mathrm{M}$ mixer-settler bank. The $1 \mathrm{CU}$ conductivity meter at the Savannah River Site (SRS) H-Canyon is a Safety Significant instrument that measures hydrogen ion concentration. The 1CU conductivity meter provides protection against an inadvertent nuclear criticality accident. If the hydrogen ion concentration of the 1CU flow stream is not within limits, a reflux condition may be indicated. Reflux is a problem where uranium in a mixer-settler bank is extracted back and forth between the aqueous and organic phases and is accumulated in the bank instead of exiting the bank. Although this work supports a campaign to process solution from Super Kukla reactor (SK) fuel dissolution, the results will be applicable to the processing of any solution of similar uranium and nitric acid concentration.

Uranium concentrations are to be as much as three times higher than historically normal levels when fuel from the SK reactor is processed in H-Canyon. H-Canyon Process Engineering requested that the $1 \mathrm{CU}$ conductivity instrument or a similar instrument be tested with solutions containing nitric acid in the range of 0.3 to $0.35 \mathrm{M}$ and uranium concentrations as high as $30 \mathrm{~g} / \mathrm{L}$. The $1 \mathrm{CU}$ instrument is a Great Lakes International Model 3700-E sensor with Model E63 transmitter. The unit operates by magnetic induction to measure conductivity of solution (units of millisiemens/cm, $\mathrm{mS} / \mathrm{cm}$ ) within the bore in the instrument head.

\subsection{SPECIFYING DOCUMENTS}

H-Canyon personnel provided a Task Technical Request titled "Flowsheet Evaluation for Processing 90\% Uranium/10\% Molybdenum (NNSA-Metals) in H-Canyon” (NMMD-HTS2006-2925). ${ }^{1}$ SRNL then provided a Task Technical and Quality Assurance Plan (TTQAP) entitled "Task Technical and Quality Assurance Plan for Conductivity Effects of Uranium in Nitric Acid". 2 This work bears similarities to testing of colorimetric instruments in the same facility. ${ }^{3}$

\subsection{EXPERIMENTAL AND ANALYSIS}

A summary of steps to complete the work in H-Canyon is listed below. Solutions containing both uranium and free acid were made per procedure in H-Canyon. ${ }^{4}$ The conductivity meter had been calibrated with acid only per normal procedure a day before pours were made using uranium bearing solution. ${ }^{5}$ Pours with uranium bearing solutions were performed on September 7, 2007. The steps were as follows: 
- $\quad$ prepare nitric acid/uranium solutions per the test matrix specified in the TTQAP;

- submit samples from each solution to Analytical Laboratories (AL) for determination of free acid, uranium content, and density;

- perform pours of the solutions through the 1CU conductivity meter, recording the conductivity readings from the meter, the free acid molarity from the control room chart recorder, and the solution temperature; and

- $\quad$ provide data to SRNL for analysis and reporting.

\subsection{CONDUCTIVITY METER}

The 1CU conductivity meter is a Great Lakes International (GLI) Model 3700-E sensor with Model E63 transmitter. The meter head passes solution through a central Teflon ${ }^{\mathrm{TM}}$ tube that is within transmitting and receiving coils. Alternating current in the transmitting coil induces a current in fluid in the central tube and the receiving coil senses the magnitude of the induced current. The induced current is proportional to electrical conductivity of the fluid. The meter hardware includes a digital readout giving conductivity in $\mathrm{mS} / \mathrm{cm}$. The meter also measures temperature, using a resistance temperature device at the sensor head, and corrects the output accordingly. The hardware provides a standard 4-20 milliamp signal to the safetysignificant chart recorder (designated HQ21) which indicates free acid molarity. The calibrating procedure assures that the chart recorder represents concentrations of free acid in standard acid solutions.

The conductivity readout at the meter is for indication only. This work found that the readout at the meter is not calibrated and should not be used for any purpose. This finding is corroborated by the experience of the engineer associated with the original installation and checkout of the meter. ${ }^{6}$ The database in this report shows that the following linear relationship, equation 1 , linked reported conductivity with reported free acid (Free $\mathrm{H}$ ). This was a calculation performed by the conductivity hardware so no error is associated with this linear relation.

$$
[\text { Free } \mathrm{H}]=([\mathrm{mS} / \mathrm{cm}]-7.6134) / 274.36
$$

\subsection{METER CALIBRATION AND UNCERTAINTIES}

The 1CU meter and chart recorder together were calibrated to within $2 \%$ absolute reading with three nitric acid/water solutions. The solutions contained no uranium and the work was done one day before uranium/nitric acid solutions were poured. This provided assurance that the meter was within calibration and working properly as determined by procedure. ${ }^{5}$ The full scale for the meter is $0.5 \mathrm{M}$ per the Installed Process Instrumentation database and acid molarity uncertainty is to be demonstrated to be less than $2 \%$ of full scale (+/-0.01 M free acid). The results of the calibration showed that the meter and chart recorder (which processes a 4-20 milliamp signal from the meter) passed calibration per Table 1 below. 
Table 1. Results of the 9/06/2007 Calibration of the 1CU Meter

\begin{tabular}{|c|c|c|c|}
\hline $\begin{array}{c}\text { Acid Solution - } \\
\text { Bottle Number }\end{array}$ & Acid Level, M & $\begin{array}{c}\text { Acceptable Acid } \\
\text { Range for HQ21 } \\
\text { Recorder, M }\end{array}$ & $\begin{array}{c}\text { Meter/HQ21 } \\
\text { Recorder } \\
\text { Reading }\end{array}$ \\
\hline A-1-SK & 0.18 & 0.17 to 0.19 & 0.1869 \\
\hline CND-14-SK & 0.35 & 0.34 to 0.36 & 0.3443 \\
\hline CND-1-SK & 0.46 & 0.45 to 0.47 & 0.4562 \\
\hline
\end{tabular}

While the meter is accurate to within $2 \%$, it is not possible to demonstrate that acid measurements for uranium-bearing solutions can be made that accurately. This problem arises because the presence of hydrolysable ions in the sample requires the use of a confirmatory analytical method that is less precise than the method for simple acid solutions. The procedure for free acid measurement with no hydrolysable ions has a one standard deviation uncertainty of $0.4 \%$ in the acid range of 2 to $60 \%(0.32$ to $\sim 13 \mathrm{M}){ }^{7}$ It is thus possible to calibrate the meter with uranium-free acid solutions where the analytical 2-sigma or $95 \%$ confidence uncertainty is $0.8 \%$, which is less than the $2 \%$ meter accuracy. However, free acid in solutions containing uranium must be measured with another procedure providing an uncertainty of $8.5 \%$ at $95 \%$ confidence. ${ }^{8}$ All solutions in this work were analyzed using the latter procedure, so the greater uncertainty in free acid level is applicable.

The effect of the greater uncertainty can be seen in Figure 1, which shows the scatter in free acid measurements when the Reference 8 procedure is used on solutions containing no uranium. For these simple solutions, the correlation between acid concentration and density is well-known, and the latter can be used to predict the former. The lines represent data from the International Critical Tables for solutions at $20{ }^{\circ} \mathrm{C}$ and $30{ }^{\circ} \mathrm{C} .{ }^{9}$ The lines bracket the AL density measurements, which were performed at a nominal $25{ }^{\circ} \mathrm{C}$ (not recorded, but specified in the procedure). ${ }^{10}$ The uncertainty of the density measurement is negligible on the scale of the graph, and the consistent density results for replicate samples indicate that any variation in acidity is not due to sampling errors. Therefore, the observed scatter in the acid results is representative of the uncertainty in the free acid method. 
Figure 1. Comparison of AL Density-Free Nitric Data with Literature

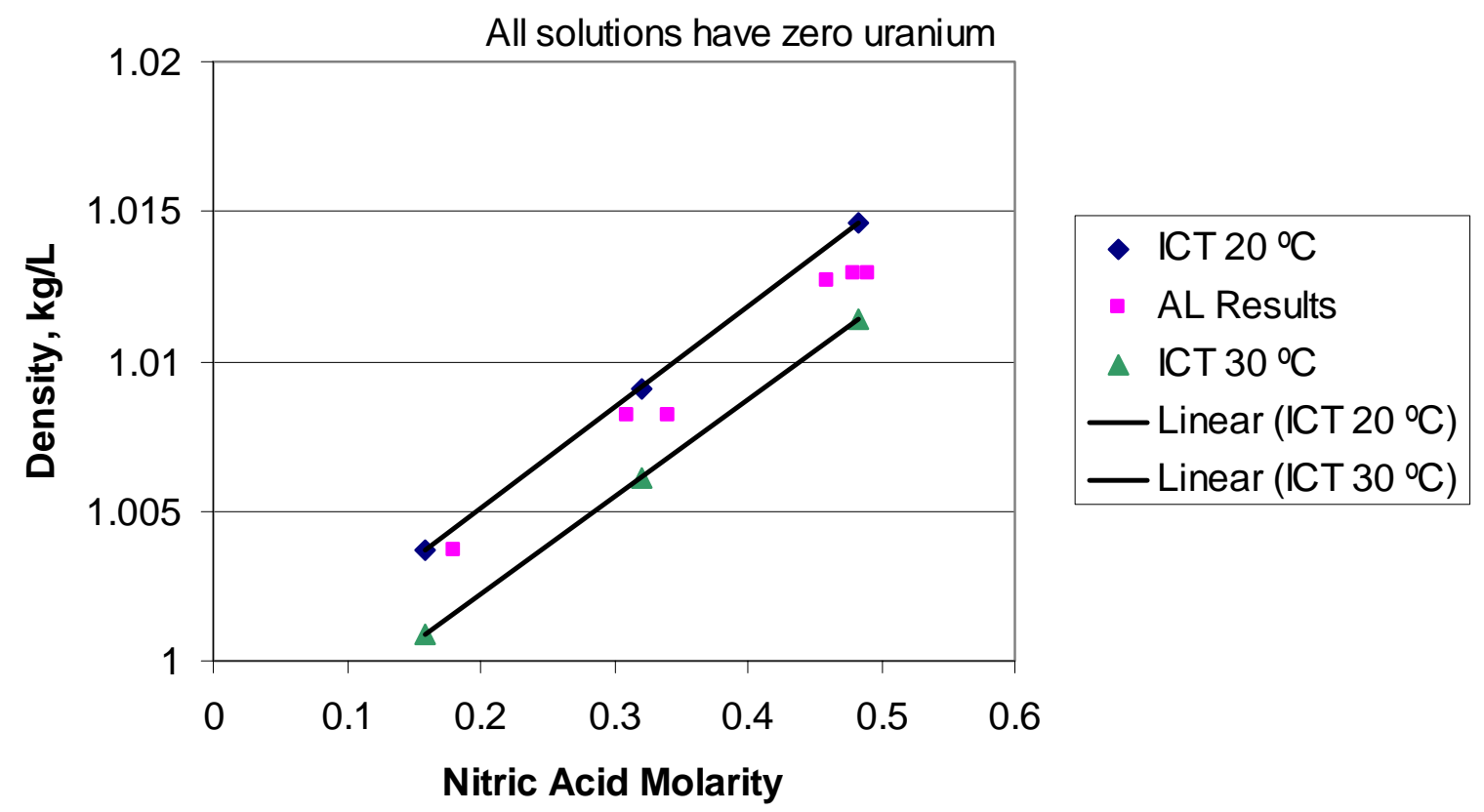

\subsection{URANIUM NITRATE SOLUTION AND ANALYSIS}

The test matrix, Table 2, varied nitric acid and uranium levels in the solutions. Note that although solution from the dissolution of SK fuel may also contain molybdenum and iron, these elements are removed by the $\mathrm{H}$-Canyon process before the uranium solution reaches the $1 \mathrm{CU}$ bank. The stream at $1 \mathrm{CU}$ would only have the two major solutes: uranium and free nitric acid.

To test expected field conditions of the 1CU stream H-Canyon Process Engineering requested that the test matrix focus on a free nitric acid level between 0.3 and $0.35 \mathrm{M}$. However, the acid molarity may range from 0.2 to $0.46 \mathrm{M}$. Table 2 below thus contains various nitric acid tests as a zero-uranium baseline. Nitric acid solution data excluding uranium are most easily compared to literature values for conductivity.

Test solutions were mixed by $\mathrm{H}$-canyon personnel according to established facility procedures from stock depleted uranium nitrate solution (DUN solution, 440 g/L uranium). Approximately 7 liters of each solution composition were made, enough for two pours. 
Table 2. Test Matrix and Resulting Data

\begin{tabular}{|c|c|c|c|c|c|c|c|}
\hline \multicolumn{2}{|c|}{ Test Matrix Targets } & \multicolumn{4}{c|}{ Measured Values from AL and H-Canyon } \\
\hline $\begin{array}{c}\text { Pour } \\
\#\end{array}$ & $\begin{array}{c}\text { Free } \\
\text { Nitric } \\
\text { Acid, } \\
\mathbf{M}\end{array}$ & $\begin{array}{c}\text { Free } \\
\text { Uranium } \\
\text { g/L }\end{array}$ & $\begin{array}{c}\text { Nitric } \\
\text { Acid } \\
\text { (Nitr), } \\
\text { M }\end{array}$ & $\begin{array}{c}\text { Uranium } \\
\text { (U), g/L }\end{array}$ & $\begin{array}{c}\text { Chart } \\
\text { Reading, } \\
\text { M free } \\
\text { acid }\end{array}$ & $\begin{array}{c}\text { Conductivity, } \\
\text { mS / cm }\end{array}$ & $\begin{array}{c}\text { Temperature } \\
\text { (T), } \mathbf{~}^{\mathbf{C}}\end{array}$ \\
\hline 1 & 0.20 & 0 & 0.18 & 0 & 0.1953 & 61.3 & 27.9 \\
\hline 2 & 0.33 & 30 & 0.35 & 30.21 & 0.3357 & 99.7 & 28 \\
\hline 3 & 0.33 & 10 & 0.295 & 9.91 & 0.3035 & 90.9 & 28.1 \\
\hline 4 & 0.20 & 20 & 0.215 & 20.1 & 0.249 & 76 & 28.1 \\
\hline 5 & 0.33 & 5 & 0.325 & 5.08 & 0.2851 & 85.8 & 27.9 \\
\hline 6 & 0.33 & 20 & 0.34 & 21 & 0.3212 & 95.7 & 28.1 \\
\hline 7 & 0.46 & 0 & 0.485 & 0 & 0.4594 & 133.5 & 28.2 \\
\hline 8 & 0.33 & 15 & 0.34 & 14.22 & 0.3384 & 100.3 & 28.2 \\
\hline 9 & 0.33 & 0 & 0.325 & 0 & 0.3068 & 91.8 & 28.2 \\
\hline 10 & 0.33 & 20 & 0.34 & 21 & 0.3412 & 101.2 & 28.2 \\
\hline 11 & 0.33 & 30 & 0.35 & 30.21 & 0.3551 & 104.8 & 28.2 \\
\hline 12 & 0.33 & 5 & 0.325 & 5.08 & 0.3151 & 94.1 & 28.3 \\
\hline 13 & 0.46 & 30 & 0.52 & 29.63 & 0.4996 & 145 & 28.3 \\
\hline 14 & 0.33 & 0 & 0.325 & 0 & 0.3434 & 101.8 & 28.2 \\
\hline 15 & 0.33 & 15 & 0.34 & 14.22 & 0.3599 & 106.4 & 28.2 \\
\hline 16 & 0.20 & 20 & 0.215 & 20.1 & 0.2362 & 72.5 & 28.2 \\
\hline
\end{tabular}

While volumes of water, DUN, and $50 \mathrm{wt} \%$ nitric acid were measured carefully in preparing the solutions, free nitric (Nitr) and uranium (U) results from AL were used as the independent variables for data analysis. Temperature $(\mathrm{T})$ was recorded at H-Canyon from the 1CU conductivity meter. Table 2 shows average measured values of AL data where duplicates are available. Appendix A contains a complete record of data. Deviations from averages are provided with the data averages in Appendix A Table A.2.

H-Canyon personnel requested that AL provide free acid level by "ACID FREE DUPLICATE M126", Procedure L3.06-10125. " This is a titration method that includes reagents to suppress interference from various metals in solution including uranium. AL provided uranium level by "U IDMS". ${ }^{11}$ The procedure used inductively couple plasmamass spectrometry (ICP-MS). While the uranium isotopic distributions by weight percent were provided, the current work only considered total uranium.

The test matrix points were randomized to help provide assurance that systematic issues like residual solution in the system were minimized. The pour numbers in Table 2 indicate chronological order. Fifteen pours were specified but a sixteenth was added because of questions around the time that pour 4 was done (a leak was found in the system). The leak was fixed quickly and the pours completed in the same day. Pour 16 is a repeat of pour 4 . 
Table 3 compares the meter reading at the chart recorder for comparable pours. The average variation between duplicates for the data set is 3.8\%, showing that replication is reasonably good. The main source of uncertainty was found to be in the AL measurement of free acid level as explained in Section 2.2. Pour numbers in Table 3 are the same chronological numbers of Table 2. It is to be noted that the later pour in most cases provided the higher value in each comparison. Regression analysis of the whole database, however, showed that there was no significant upward drift in the meter reading with time or pour order.

Table 3. Comparison of Meter Reading for Replicated Pours

\begin{tabular}{|c|c|c|c|}
\hline Pours Compared & $\begin{array}{c}\text { Earlier Pour } \\
\text { [Free H, M] }\end{array}$ & $\begin{array}{c}\text { Later Pour } \\
\text { [Free H, M] }\end{array}$ & $\begin{array}{c}\text { Percent } \\
\text { Variation from } \\
\text { Average }\end{array}$ \\
\hline $2 \& 11$ & 0.3357 & 0.3551 & 2.8 \\
\hline $5 \& 12$ & 0.2851 & 0.3151 & 5.0 \\
\hline $6 \& 10$ & 0.3212 & 0.3412 & 3.0 \\
\hline $8 \& 15$ & 0.3384 & 0.3599 & 3.0 \\
\hline $9 \& 14$ & 0.3068 & 0.3434 & 5.6 \\
\hline $4 \& 16$ & 0.249 & 0.2362 & 3.1 \\
\hline
\end{tabular}

\subsection{LINEAR REGRESSION ANALYSIS OF DATA}

Standard linear regression in an EXCEL spreadsheet was used to assess dependent variable (reported free nitric acid molarity) sensitivities to the independent variables Nitr, U, and T. In addition the regression modeling examined the effect of pour order. Sensitivities were assessed by comparing P-values of independent variables of the various models. The P-value compares each model coefficient divided by its standard error to the Student's t statistic. It is a measure of significance of the independent variable being tested. Since calculations were performed at the 95\% confidence level P-values of less than 0.05 were desired. Initial models including many independent variables were unlikely to provide P-values less than 0.05 but did provide relative sensitivity of the dependent variable free acid [Free $\mathrm{H}$ ] to each independent variable.

The first model examined the relative effect of all independent variables [pour order], a constant, Nitr, $\mathrm{U}$, and $\mathrm{T}$ and in addition included quadratic terms $[\mathrm{Nitr}]^{2}, \mathrm{U}^{2}$, and Nitr*U. The model that was first examined is equation 2 below, where the lowercase parameters $a, b$, through g are linear regression coefficients.

$$
\text { [Free } \mathrm{H}]=\mathrm{a}+\mathrm{b} *[\text { pour order }]+\mathrm{c}^{*}[\mathrm{Nitr}]+\mathrm{d} *[\mathrm{Nitr}]^{2}+\mathrm{e}^{*} \mathrm{U}+\mathrm{f}^{*} \mathrm{U}^{2}+\mathrm{g} *[\mathrm{Nitr}] * \mathrm{U}
$$

This first step showed that pour order and $\mathrm{U}^{2}$ were the least useful $(\mathrm{P}>0.85)$. Removal of these provided a model where $U$ and Nitr*U were least useful. A model including only a constant, [Nitr], [Nitr $]^{2}$, and $\mathrm{T}$ showed that $[\mathrm{Nitr}]^{2}$ should be excluded. A model having a constant, [Nitr], U, and T showed that U should be excluded. A model checking only [Nitr] 
and pour order showed that only [Nitr] was significant. The two simplest models involving [Nitr] are:

$$
\text { [Free } \mathrm{H}]=0.9931 *[\mathrm{Nitr}] \quad(\text { std. estimate of error } 0.018 \mathrm{M})
$$

and

$$
[\text { Free } \mathrm{H}]=0.050945+0.8485 *[\mathrm{Nitr}](\text { std. estimate of error } 0.013 \mathrm{M})
$$

These linear relations are only valid for a [Nitr] between 0.18 and $0.52 \mathrm{M}$ and a temperature range of 27.9 to $28.3{ }^{\circ} \mathrm{C}$. The P-value for [Nitr] in each case was found to be less than $10^{-10}$, or essentially zero. The correlation of free acid reported by the meter to free acid in solution was thus found to be significant beyond any reasonable doubt. The fits of both equation 3 and 4 excluded pour 5 in the dataset because this point was found to have more residual error than the other points, consistent with the experimental note in the dataset that this point was questionable. See the experimental notes in Appendix A.

The near-unity value of the coefficient of [Nitr] in equation 3 is significant. It shows that the calibration of the conductivity meter, precalibrated with only nitric acid solutions, is confirmed when solutions containing uranium with nitric acid are used. The other variables, and notably uranium concentration, are not significant in this range of free acid, uranium concentration, and temperature. Farrar also found that uranium did not create a significant effect on the free acid reading from the 1EU conductivity meter at a similar range of free nitric acid molarity. ${ }^{12}$ That work, however, only examined data up to a uranium concentration of about $4 \mathrm{~g} / \mathrm{L}$. A further examination of the effect of uranium on electrical conductivity in solutions with free nitric acid is provided in Appendix B.

\subsection{CONCLUSIONS}

- The existing 1CU conductivity meter for free acid concentration measurement and calibration may be used for processing of Super Kukla fuel without modification for the sake of uranium concentration up to $30 \mathrm{~g} / \mathrm{L}$.

- Free acid level, M, as indicated by the $1 \mathrm{CU}$ conductivity meter and chart recorder, was found to be independent of uranium concentration in the range of 0.18 to $0.52 \mathrm{M}$ free acid, 0 to $30 \mathrm{~g} / \mathrm{L}$ uranium, and 27.9 to $28.3^{\circ} \mathrm{C}$.

- Literature work shows that at a free acid level of $0.33 \mathrm{M}$, uranium concentration of 30 $\mathrm{g} / \mathrm{L}$, and temperature of $25{ }^{\circ} \mathrm{C}$, that solution conductivity would be $96.4 \%$ of that of a uranium-free solution. Given the uncertainty in the literature work this 3.6\% reduction in uncertainty is not significant for the $1 \mathrm{CU}$ meter at uranium concentration up to $30 \mathrm{~g} / \mathrm{L}$

- AL procedures provide free acid with a 2-sigma uncertainty of $0.8 \%$ when no uranium is present in the solutions. The uncertainty rises to $8.5 \%$ when uranium or other hydrolysable ions are present. The increased uncertainty impacts the effort to detect a uranium effect on conductivity. 
- The for-information-only conductivity reading at the meter was found to trend significantly below absolute conductivity of the solution in the 0.18 to $0.52 \mathrm{M}$ acid range.

- Absolute conductivity varies $10 \%$ between the temperatures of 20 to $28{ }^{\circ} \mathrm{C}$ at a free acid level of $0.33 \mathrm{M}$. The conductivity meter correction for temperature is thus important.

\subsection{RECOMMENDATIONS}

Do not use the conductivity readout at the $1 \mathrm{CU}$ meter for any purpose unless work is done to calibrate it. In contrast the meter and the use of its signal at the chart recorder to report free acid molarity have been shown to be suitable for use.

\subsection{ACKNOWLEDGEMENTS}

Stephanie Hudlow and Matt Garrett are gratefully acknowledged for their work in preparing uranium and nitric acid solutions for the work, submitting samples to AL, and working with the facility to perform the pours. H-Canyon Operations is also acknowledged for providing support for the in-facility testing.

\subsection{REFERENCES}

${ }^{1}$ W. H. Clifton, TTR entitled "Flowsheet Evaluation for processing $90 \%$ Uranium $/ 10 \%$ Molybdenum (NNSA-Metals) in H-Canyon” (NMMD-HTS-2006-2925)”, Rev. 0, March 15, 2007.

2 C. A. Nash, "Task Technical And Quality Assurance Plan For Conductivity Effects Of Uranium In Nitric Acid”, WSRC-STI-RP-2007-00381, May 22, 2007

${ }^{3}$ R. Lascola, "Characterization of H-Canyon Colorimeter Performance at Extended Uranium Concentrations", WSRC-STI-TR-00217, April, 2007

4 “Makeup of 1CU Conductivity Calibration Solution”, Procedure NOP 221H-4313, revision 6, 10/26/2004.

${ }^{5}$ GLI Analytical, Direct Reading Conductivity Meter - Controller Solu Meter E63, Calibration”, UET Procedure MAINT H-706016, revision 11, effective 01-27-2006, performed 09/06/2007.

${ }^{6}$ M. E. Farrar, personal communication, ”Absolute Measurement of Conductivity", 10/09/2007.

7 “Acid Analysis: Automatic Titration Method”, Procedure L3.06-10113, revision 2, $11 / 04 / 2004$.

8 “Free Acid: Interface Control Program”, Procedure L3.06-10125, revision 1, 12/01/2006.

${ }^{9}$ International Critical Tables of Numerical Data, Physics, Chemistry, and Technology, first edition, Vol. III, E. W. Washburn, Editor, published by McGraw-Hill Book Company, New York, 1928. 
10 “Density: Anton Paar DMA Series”, Procedure L3.06-10116, revision 1, 06/12/2006.

11 “Uranium: Isotopic Dilution Mass Spec-NSS”, Procedure L3.05-10039.01, revision 2, 9/10/2002.

12 M. E. Farrar, “Calibration of 1CU and 1EU Conductivity Meters”, SRT-IES-2003-00089, February 17, 2004.

13 B. B. Spencer, "Simultaneous Determination of Nitric Acid And Uranium Concentrations in Aqueous Solutions From Measurements of Electrical Conductivity, Density, and Temperature”, CONF-910901-1, Fourth International Conference on Facility Operations - Safeguards Interface, p. 115-128, September 29-October 4, 1991.

14 Handbook of Chemistry and Physics, $56^{\text {th }}$ edition, R. C. Weast, editor, page D-238, Published by CRC Press, Cleveland, OH, 1976 
WSRC-STI-2007-00500, Rev. 0

\section{APPENDIX A: Tables of Test Data}

Table A.1. Averaged Results and Notes on Pours

\begin{tabular}{|c|c|c|c|c|c|c|c|c|}
\hline \multirow[b]{2}{*}{ Bottle \# } & \multirow[b]{2}{*}{ Pour Number } & \multicolumn{2}{|c|}{ Targeted Values } & \multicolumn{2}{|c|}{ Sample Results } & \multirow{2}{*}{$\begin{array}{c}\text { Recorder } \\
\text { M }\end{array}$} & \multirow{2}{*}{$\begin{array}{c}\begin{array}{c}\text { Conductivity } \\
\text { Meter reading }\end{array} \\
\mathrm{mS} / \mathrm{cm}\end{array}$} & \multirow{2}{*}{$\begin{array}{c}\text { Temperature } \\
\text { deg. } C \\
\end{array}$} \\
\hline & & $\begin{array}{c}\text { Free Nitric } \\
\text { Acid M }\end{array}$ & Uranium g/L & $\begin{array}{l}\text { Free Nitric } \\
\text { Acid M }\end{array}$ & Uranium g/L & & & \\
\hline A-1-SK & 1 & 0.2 & $\mathbf{0}$ & 0.18 & 0 & 0.1953 & 61.3 & 27.9 \\
\hline CND-11-SK & 2 & 0.33 & 30 & 0.35 & 30.21 & 0.3357 & 99.7 & 28 \\
\hline A-2-SK & 3 & 0.33 & 10 & 0.295 & 9.91 & 0.3035 & 90.9 & 28.1 \\
\hline A-3-SK & 4 & 0.2 & 20 & 0.215 & 20.1 & 0.249 & 76 & 28.1 \\
\hline CND-12-SK & 5 & 0.33 & 5 & 0.325 & 5.08 & 0.2851 & 85.8 & 27.9 \\
\hline CND-10-SK & 6 & 0.33 & 20 & 0.34 & 21 & 0.3212 & 95.7 & 28.1 \\
\hline CND-16-SK & 7 & 0.46 & $\mathbf{0}$ & 0.485 & $\mathbf{0}$ & 0.4594 & 133.5 & 28.2 \\
\hline CND-15-SK & 8 & 0.33 & 15 & 0.34 & 14.22 & 0.3384 & 100.3 & 28.2 \\
\hline CND-9-SK & 9 & 0.33 & $\mathbf{0}$ & 0.325 & $\mathbf{0}$ & 0.3068 & 91.8 & 28.2 \\
\hline CND-10-SK & 10 & 0.33 & 20 & 0.34 & 21 & 0.3412 & 101.2 & 28.2 \\
\hline CND-11-SK & 11 & 0.33 & 30 & 0.35 & 30.21 & 0.3551 & 104.8 & 28.2 \\
\hline CND-12-SK & 12 & 0.33 & 5 & 0.325 & 5.08 & 0.3151 & 94.1 & 28.3 \\
\hline A-4-SK & 13 & 0.46 & 30 & 0.52 & 29.63 & 0.4996 & 145 & 28.3 \\
\hline CND-9-SK & 14 & 0.33 & $\mathbf{0}$ & 0.325 & $\mathbf{0}$ & 0.3434 & 101.8 & 28.2 \\
\hline CND-15-SK & 15 & 0.33 & 15 & 0.34 & 14.22 & 0.3599 & 106.4 & 28.2 \\
\hline A-3-SK & $4(16)$ & 0.2 & 20 & 0.215 & 20.1 & 0.2362 & 72.5 & 28.2 \\
\hline Bottle \# & Test Number & \multicolumn{7}{|l|}{ Comments } \\
\hline A-1-SK & 1 & & & & & & & \\
\hline CND-11-SK & 2 & \\
\hline A-2-SK & 3 & \multicolumn{7}{|c|}{ Reading jumped to 0.35 while draining. } \\
\hline A-3-SK & 4 & \multirow{2}{*}{\multicolumn{7}{|c|}{$\begin{array}{l}\text { Not completely to zero before pour. Rose then dropped. Continued to rise. Discovered leak on valve. Test } \\
\text { suspended. }\end{array}$}} \\
\hline CND-12-SK & 5 & & & & & & & \\
\hline CND-10-SK & 6 & \multicolumn{7}{|c|}{ Jumped to 0.342 while draining. } \\
\hline CND-16-SK & 7 & \multicolumn{7}{|c|}{ Jumped to 0.469 while draining. Up to 0.4755 before draining complete. } \\
\hline
\end{tabular}

Notes: Free nitric and uranium sample results are averages of duplicate measurements.

Pour 4 was repeated at the end of the work and thus provides a sixteenth pour. 
WSRC-STI-2007-00500, Rev. 0

Table A.2. Raw Data Including AL Sample Identification

\begin{tabular}{|c|c|c|c|c|c|c|c|c|}
\hline \multirow[b]{2}{*}{ Bottle \# } & \multirow[b]{2}{*}{ Lab Sample ID } & \multirow[b]{2}{*}{ Pour Number } & \multicolumn{3}{|c|}{ Measurements } & \multicolumn{3}{|c|}{ Averages and Levels of Error* } \\
\hline & & & Density, g/mL & $\begin{array}{l}\text { Free Nitric } \\
\text { Acid M }\end{array}$ & Uranium, g/L & $\begin{array}{c}\text { Density, g/mL, } \\
\text { error }\end{array}$ & $\begin{array}{c}\text { Free Nitric } \\
\text { Acid M, } \\
\text { error }\end{array}$ & $\begin{array}{c}\text { Uranium } g / L \text {, } \\
\text { error }\end{array}$ \\
\hline A-1-SK & 200454844 & 1 & 1.0037 & 0.18 & 0 & 1.0037 & 0.18 & 0.00 \\
\hline A-1-SK & 200454845 & 1 & 1.0037 & 0.18 & 0 & 0 & 0.00 & 0.00 \\
\hline CND-11-SK & 200451493 & 2 & 1.0495 & 0.36 & 30.28 & 1.0495 & 0.35 & 30.21 \\
\hline CND-11-SK & 200451494 & 2 & 1.0495 & 0.34 & 30.13 & 0 & 0.01 & 0.11 \\
\hline A-2-SK & 200454846 & 3 & 1.02 & 0.3 & 9.94 & 1.02 & 0.30 & 9.91 \\
\hline A-2-SK & 200454847 & 3 & 1.02 & 0.29 & 9.88 & 0 & 0.01 & 0.04 \\
\hline A-3-SK & 200455150 & 4 & 1.0315 & 0.22 & 20.28 & 1.0313 & 0.215 & 20.10 \\
\hline A-3-SK & 200455153 & 4 & 1.0311 & 0.21 & 19.92 & 0.000282843 & 0.01 & 0.25 \\
\hline CND-12-SK & 200451495 & 5 & 1.0146 & 0.31 & 5.089 & 1.0146 & 0.33 & 5.08 \\
\hline CND-12-SK & 200451496 & 5 & 1.0146 & 0.34 & 5.073 & 0 & 0.02 & 0.01 \\
\hline CND-10-SK & 200451491 & 6 & 1.0367 & 0.34 & 20.99 & 1.03675 & 0.34 & 21.00 \\
\hline CND-10-SK & 200451492 & 6 & 1.0368 & 0.34 & 21 & 7.07107E-05 & 0.00 & 0.01 \\
\hline CND-16-SK & 200456390 & 7 & 1.0129 & 0.49 & 0 & 1.0129 & 0.485 & 0.00 \\
\hline CND-16-SK & 200456391 & 7 & 1.0129 & 0.48 & 0 & 0 & 0.007 & 0.00 \\
\hline CND-15-SK & 200451501 & 8 & 1.0278 & 0.34 & 14.23 & 1.0278 & 0.34 & 14.22 \\
\hline CND-15-SK & 200451502 & 8 & 1.0278 & 0.34 & 14.21 & 0 & 0.00 & 0.01 \\
\hline
\end{tabular}

*Note: Averages are the upper number for each solution and error in that average is the lower number of the set. The error value is the standard deviation applied to each pair of AL measurements. 
WSRC-STI-2007-00500, Rev. 0

Table A.2, Continued. Raw Data Including AL Sample Identification

\begin{tabular}{|c|c|c|c|c|c|c|c|c|}
\hline & & & \multicolumn{3}{|c|}{ Measurements } & \multicolumn{3}{|c|}{$\begin{array}{l}\text { Averages and Levels of Error* } \\
\end{array}$} \\
\hline Bottle \# & $\begin{array}{c}\text { Lab Sample } \\
\text { ID }\end{array}$ & Pour Number & Density, g/mL & $\begin{array}{c}\text { Free Nitric } \\
\text { Acid M }\end{array}$ & Uranium g/L & Density, g/mL & $\begin{array}{c}\text { Free Nitric } \\
\text { Acid M }\end{array}$ & Uranium g/L \\
\hline CND-9-SK & 200451489 & 9 & 1.0082 & 0.34 & 0 & 1.0082 & 0.33 & 0.00 \\
\hline CND-9-SK & 200451490 & 9 & 1.0082 & 0.31 & 0 & 0 & 0.02 & 0.00 \\
\hline CND-10-SK & 200451491 & 10 & 1.0367 & 0.34 & 20.99 & 1.03675 & 0.34 & 21.00 \\
\hline CND-10-SK & 200451492 & 10 & 1.0368 & 0.34 & 21 & 7.07107E-05 & 0.00 & 0.01 \\
\hline CND-11-SK & 200451493 & 11 & 1.0495 & 0.36 & 30.28 & 1.0495 & 0.35 & 30.21 \\
\hline CND-11-SK & 200451494 & 11 & 1.0495 & 0.34 & 30.13 & 0 & 0.01 & 0.11 \\
\hline CND-12-SK & 200451495 & 12 & 1.0146 & 0.31 & 5.089 & 1.0146 & 0.33 & 5.08 \\
\hline CND-12-SK & 200451496 & 12 & 1.0146 & 0.34 & 5.073 & 0 & 0.02 & 0.01 \\
\hline A-4-SK & 200455151 & 13 & 1.054 & 0.52 & 29.41 & 1.05375 & 0.52 & 29.63 \\
\hline A-4-SK & 200455152 & 13 & 1.0535 & 0.52 & 29.84 & 0.000353553 & 0.00 & 0.30 \\
\hline CND-9-SK & 200451489 & 14 & 1.0082 & 0.34 & 0 & 1.0082 & 0.33 & 0.00 \\
\hline CND-9-SK & 200451490 & 14 & 1.0082 & 0.31 & 0 & 0 & 0.02 & 0.00 \\
\hline CND-15-SK & 200451501 & 15 & 1.0278 & 0.34 & 14.23 & 1.0278 & 0.34 & 14.22 \\
\hline CND-15-SK & 200451502 & 15 & 1.0278 & 0.34 & 14.21 & 0 & 0.00 & 0.01 \\
\hline A-3-SK & 200455150 & $16^{*}$ & 1.0315 & 0.22 & 20.28 & 1.0313 & 0.215 & 20.10 \\
\hline A-3-SK & 200455153 & $16^{*}$ & 1.0311 & 0.21 & 19.92 & 0.000282843 & 0.01 & 0.25 \\
\hline
\end{tabular}

*Note: Averages are the upper number for each solution and error in that average is the lower number of the set. The error value is the standard deviation applied to each pair of AL measurements. 


\section{APPENDIX B: Comparison of Nitric Acid Conductivity with Literature}

While this work shows that chart recorder molarity is independent of uranium concentration, comparison of reported conductivity was typically found to be lower than absolute values provided in the literature. Figure B. 1 shows a comparison of the conductivity meter readout values with a correlation by Spencer. ${ }^{13}$

Spencer's model for conductivity of nitric acid in water is provided by equation A below. It is valid over a range of [Nitr] from 0.1 to $10 \mathrm{M}$ and $\mathrm{T}$ from 0 to $100{ }^{\circ} \mathrm{C}$. Maximum error of the Spencer model is less than $4.6 \%$ in the given ranges of independent variables.

Figure B.1. Comparison of Conductivity Meter Reading with Literature

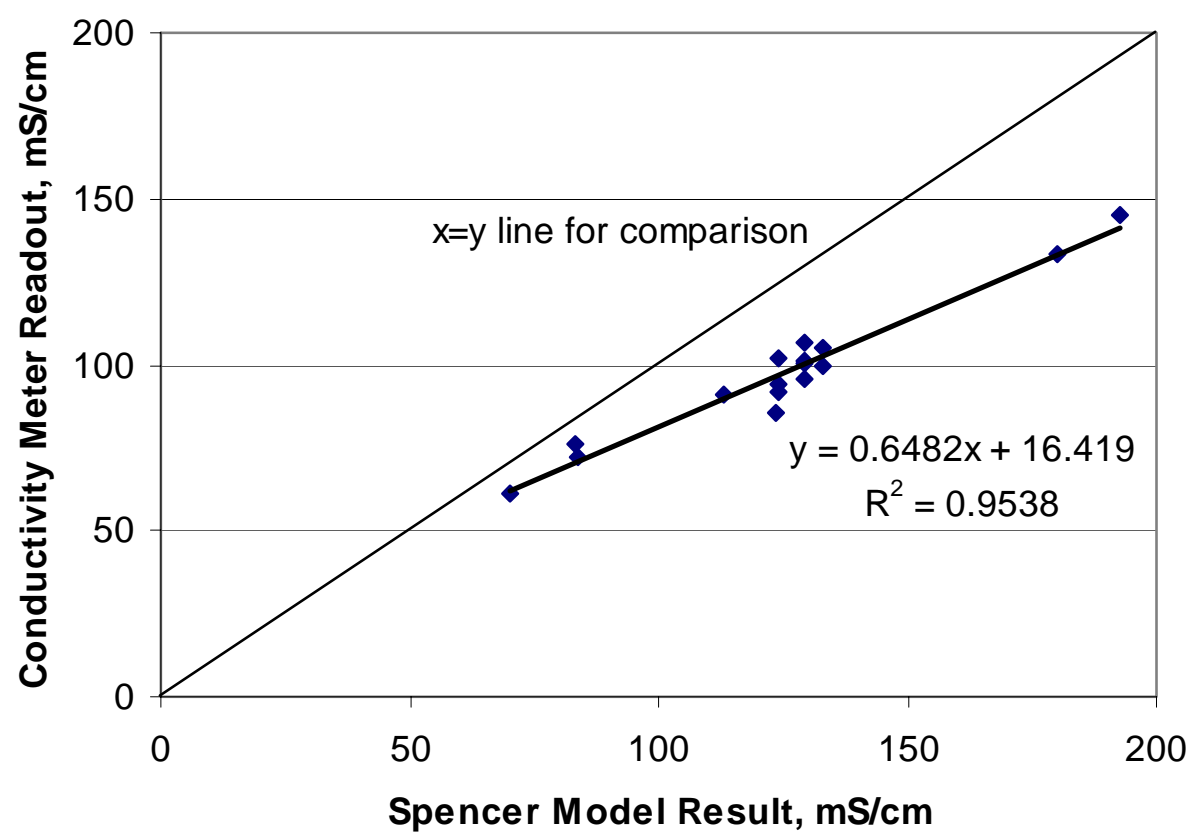

Comparison of Spencer's model with data from the CRC Handbook (0.08 to $0.56 \mathrm{M})$ found agreement to within $2 \%$. ${ }^{13,14}$

[conductivity, $\mathrm{mS} / \mathrm{cm}]=[\mathrm{Nitr}] *[255.7921+5.446796 * \mathrm{~T}-8.49695 * \mathrm{~T} * \mathrm{~T} / 1000]+$ $[\mathrm{Nitr}]^{2} *[-36.42003-1.043629 * \mathrm{~T}]+$

$[\mathrm{Nitr}]^{3} *[1.437531+0.1310446 * \mathrm{~T}]-$

$[\mathrm{Nitr}]^{4} *[6.48670 * \mathrm{~T} / 1000]$

Since the linear regression analysis did not reveal that uranium concentration had a significant effect on conductivity meter readings of free acid, literature were consulted to see what magnitude any effect might be. Spencer provides a function of acid molarity, uranium concentration $(\mathrm{g} / \mathrm{L})$ and temperature that is a dimensionless multiplier on the uranium-free conductivity of nitric-water solutions. ${ }^{13}$ If $[$ Free $\mathrm{H}]=0.33 \mathrm{M}, \mathrm{U}=30 \mathrm{~g} / \mathrm{L}$, and $\mathrm{T}=25{ }^{\circ} \mathrm{C}$ are 
entered into this function, one finds that conductivity is $96.4 \%$ of that for $0.33 \mathrm{M}$ free acid without uranium. Uranium reduces total conductivity when present. However, Spencer notes that his equation fits his data within $2.75 \%$. Spencer does not report the uncertainty of the data itself, but such uncertainty would only increase the absolute uncertainty above $2.75 \%$. Correction of the $1 \mathrm{CU}$ system based on the $3.6 \%$ calculated depression in conductivity is thus not justified.

This report does not examine the effect of temperature on conductivity because the data were taken in a relatively tight range of 27.9 to $28.3{ }^{\circ} \mathrm{C}$. Conductivity is a reasonably strong function of temperature as shown by the Spencer correlation plotted in Figure B.2.

Figure B.2. Solution Conductivity versus Temperature at Constant Free Acid

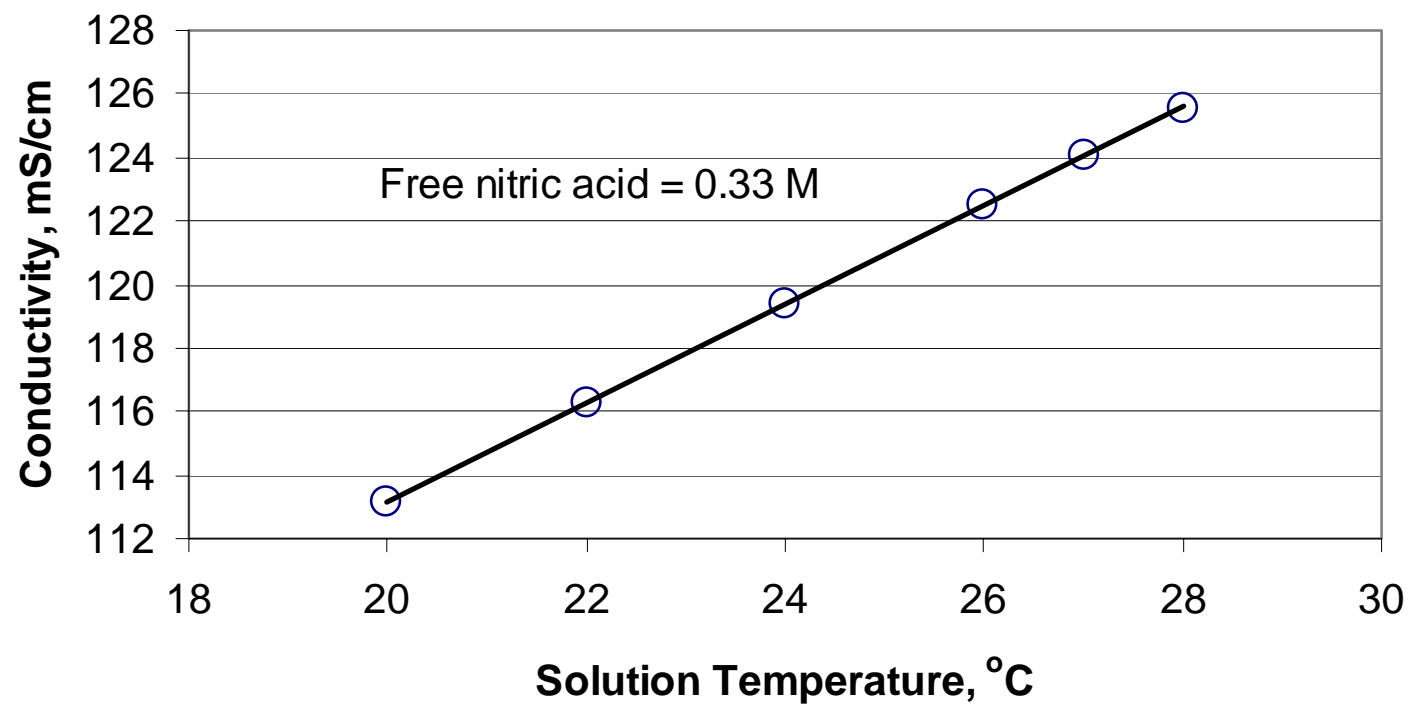

